\title{
Coastal Changes along Gamasa Beach, Egypt
}

Bahaa A El-Sharnouby', Kassem S El-Alfy ${ }^{2}$, Osami S Rageh ${ }^{3}$ and Mohammed M El-Sharabasy ${ }^{2 *}$

${ }^{1}$ Faculty of Engineering, Alexandria University, Egypt

${ }^{2}$ Irrigation \& Hydraulics Department, Faculty of Engineering, Mansoura University, Egypt

${ }^{3}$ Professor of Harbor Engineering, Faculty of Engineering, Mansoura University, Egypt

\begin{abstract}
Gamasa Beach is considered a long strip beach of white sand on the Nile Delta, Egypt. Gamasa resort locates on a very active concave shoreline which covering $30 \mathrm{~km}$ along Nile Delta Coast. Two techniques were used to monitoring shorelines, multi-spectral imagery from Landsat satellite and Global Positioning System (GPS) surveying technique. This research paper presents shoreline maps illustrating the shoreline erosion accretion pattern along Gamasa Beach by using different sources of remote sensing data. In the present study, Landsat TM (1984, 1987, 1990, 1999, 2000, 2002), Landsat ETM (2001, 2003, 2005, 2010) and Landsat OLI/TIRS $(2013,2014)$ satellite images were used. Post-Processed Kinematic (PPK) points are measured by the author for extracting of Gamasa shoreline. Occupation times for survey points are on the order of seconds. Data must be post-processed to achieve high-precision results; this requires a processing program Lecia Office Software. Digital Shoreline Analysis System (DSAS) model is used to calculate the annual rate of shoreline change (erosion or accretion) between 1984 and 2014. Rates of shoreline changes are estimated from three statistical approaches of DSAS (End point rate, Linear regression rate, Least median of square). The results were validated with field observations of beach profile survey data at the same corresponding positions and time. Results showed that Gamasa beach had insignificant eroded and lower accretion between 1984 and 2014 with average rates of $5.0 \mathrm{~m} /$ year. Finally, shoreline change prediction model for coastal zone at Gamasa beach in years 2020, 2030, 2040, 2050and 2060 is estimated according to DSAS settings and Linear regression rate.
\end{abstract}

Keywords: Gamasa; Landsat image; GPS; ERDAS imagine; GIS; Shoreline changes

Abbreviations: TM: Thematic Mapper; ETM: Enhanced Thematic Mapper; ETM+: Enhanced Thematic Mapper Plus; OLI: Operational Land Imager; TIRS: Thermal Infrared Sensor; GIS: Geographic Information System; HTL: high tide line; LRR: Linear regression rate; EPR: End point rate; LMS: Least median of square

\section{Introduction}

The total length of the Egyptian Mediterranean coastline is about $995 \mathrm{~km}$. The Nile Delta shoreline, which forms $1 / 3$ of the total of length, faces serious erosion has been observed along some beaches of the Nile Delta. This erosion is largely the result of the cutoff of the sediment supply due to dam construction on the river. In the absence of a sediment supply, the continued transport of beach sediments by waves and currents towards the east has resulted in dramatic erosion of the promontories, while shoreline accretion has continued further to the east. The eroded sand is generally transported along the shore towards the east due to the prevailing wave arrived from the northwest.

There are four major public resort beaches situated along the delta coast at Baltim, Gamasa, Ras EL Bar and Portsaid. Baltim and Ras El Bar beaches are located in areas of coastal erosion and are artificially protected by detached breakwaters and groins. On the other hand, the beaches of Gamasa and portsaid are located on an accretionary shoreline of unprotected embayment, while portsaid beach is situated on sand accumulated on the up-drift side of portsaid entrance jetty.

Change detection is the process of identifying differences in the state of an object as a shoreline by observing it at different periods. Remote sensing has widely been used in environmental change detection studies. ERDAS Imagine software was used to perform image processing of satellite image. In addition image digitizing was applied for delineating the shoreline trend at the study area using the ArcGIS V. 10.1 Software Package.
Global Positioning System (GPS) had become a standard surveying technique in most surveying practices due to its ease and precision. The techniques that are commonly used now (field data methods) are Static positioning, Fast Static positions, Post-Processed Kinematic (PPK) positioning and Real-Time Kinematic (RTK) positioning. Post processed kinematic survey methods provide the surveyor with a technique for high production Cadastral Measurements and can be used in areas with minimal obstructions of the satellites. PPK uses significantly reduced observation times compared to static or fast-static observations. This method requires a least squares adjustment or other multiple baseline statistical analysis capable of producing a weighted mean average of the observations. Occupation times for survey points are on the order of seconds. Data must be post-processed to achieve high-precision results; this requires a processing program using Lecia Office Software. PPK surveys require data from at least two receivers: a 'base' (reference) receiver and a 'rover' (moving) receiver.

Digital Shoreline Analysis System (DSAS) is a freely available software application that works within the Environmental Systems Research Institute (ESRI) Geographic Information System. DSAS Version 4.2, which released in August 2010, is used at this study to compute the rate-of-change for a time series of shoreline vector data statistically. The Digital Shoreline Analysis System (DSAS) is computer

*Corresponding author: Mohammed M. El-Sharabasy, Irrigation \& Hydraulics Department, Faculty of Engineering, Mansoura University, Egypt; Tel: +20502383781; E-mail: eng.elsharabasy@yahoo.com

Received October 29, 2014; Accepted December 26, 2014; Published January 05, 2015

Citation: El-Sharnouby BA, El-Alfy KS, Rageh OS, El-Sharabasy MM (2015) Coastal Changes along Gamasa Beach, Egypt. J Coast Zone Manag 18: 393. doi: $10.4172 / 2473-3350.1000393$

Copyright: (C) 2015 El-Sharnouby BA, et al. This is an open-access article distributed under the terms of the Creative Commons Attribution License, which permits unrestricted use, distribution, and reproduction in any medium, provided the original author and source are credited. 
software that computes rate-of-change statistics from multiple historic shoreline positions residing in a GIS. It is also useful for computing rates of change for just about any other boundary change problem that incorporates a clearly-identified feature position at discrete times.

Many researchers use the remote sensing techniques to study the coastal changes. Alesheikh et al. [1] evaluated the accuracy of remote sensing techniques and a ground truth map for extracted the coastline of Urmia lake and Hyersaline lake using three Landsat 7 ETM+ images; three Landsat 5 TM images; three Landsat 4 TM images. EL-Banna and E. Hereher [2] detected temporal shoreline changes and erosionaccretion rates, using remote sensing, and their associated sediment characteristics along the coast of North Sinai, Egypt. Siripong [3] dectect the coastline changes in Thailand by remote sensing using landsat image 4 and landsat image 5. Frihy and Dewidar [4] used the Landsat Multi-spectral Scanner (MSS) and (ETM+) digital data to monitor coastal changes along the North-eastern Nile Delta. ELAsmar and El-Hereher [5] investigated the change detection of the coastal zone east of the Nile Delta using a set of four satellite images from the Multi-Spectral Scanner (MSS), Thematic Mapper (TM) and systems Pour Observation de la Terre (SPOT). Kun yu et al. [6] presents shoreline changes in west-central Florida between 1987 and 2008 using nine Landsat Thematic (TM) images. Dewidar [7] presented shoreline maps illustrating the shoreline erosion accretion pattern in the coastal area between Marsa-Alam and Hamata of Red Sea coastline by using different sources of remote sensing data, Landsat MSS (1972), Landsat TM (1990), Landsat ETM+ $(1998,2000)$ and Terra Aster (2007) satellite images were used. Bouchahma and Yan presents measurements of changes on Dierba Island of Tunisian using image processing techniques and landsat TM and ETM data. Prukpitikul et al. [8] presents shoreline change prediction model for coastal zone management in Thailand using Landsat-5 TM images acquired during 1999-2009. EL-Asmar et al. [9] used images from different satellites sensors MSS, TM, SRTM from 1973 to 2003, and presented the major environment hazards facing the coastal wetlands (Manzala and Burullus) of the Nile Delta.
Mukhopadhyay et al. [10] analyzed the change in coastline due to erosion / accretion and provide best estimate of future shoreline positions based on past shorelines in Puri coast bay of Bengal, India using Landsat imageries of 1972, 2001and 2010. Mahapatra et al. [11] investigated the shoreline changes along the South Gujarat coast using multi temporal satellite images of Landsat MSS (1972), Landsat TM (1990), Landsat ETM (2001) and IRS P6, LISS-IV (2011). Ali Niya et al. [12] investigated shoreline detection for Persian Gulf in Bushehr provinvce, Iran using remote sensing and GIS, The digital images used two Landsat 7 ETM+ images and one Landsat 5 TM images. Philip et al. [13] explored shoreline extraction methods for multi-spectral satellite imageries using Five shoreline positions were extracted for 1986, 1991, 2001, 2007 and 2011 covering a medium term of 25 years period in the Eastern coast of Ghana.

\section{Study area}

The study area constitutes the central part of the northern coastal area extending from 2-km behind Gamasa drain to western boundary of Dakhliya governorate for a distance about $30 \mathrm{~km}$. This area is located between Latitudes $31^{\circ} 28^{\prime} 00^{\prime \prime}$ and $31^{\circ} 31^{\prime} 00^{\prime \prime} \mathrm{N}$ and longitudes $31^{\circ} 21^{\prime} 00^{\prime \prime}$ and $30^{\circ} 50^{\prime} 00^{\prime \prime} \mathrm{E}$ and covered a surface area about $380 \mathrm{~km}^{2}$. Gamasa beach is one of the most important public beaches along the Nile Delta coast and is located about $30 \mathrm{~km}$ east of the Baltim beach as shown in Figure 1. Gamasa resort is located on a very active concave shoreline which covering $10 \mathrm{~km}$ along Nile Delta Coast. Gamasa beach remained unprotected until now. Gamasa Drain is lies in the eastern limit of the study area and flows south to north. The shape of drain is nearly curved protected by the eastern and northern jetties at the end as shown in Figure 2.

\section{Materials and Methods}

\section{Tidal data and their influence on determination of coastline}

Among the cyclical variations, tides cause rapid sea level variations; therefore, it is fundamental to evaluate such effects during the image

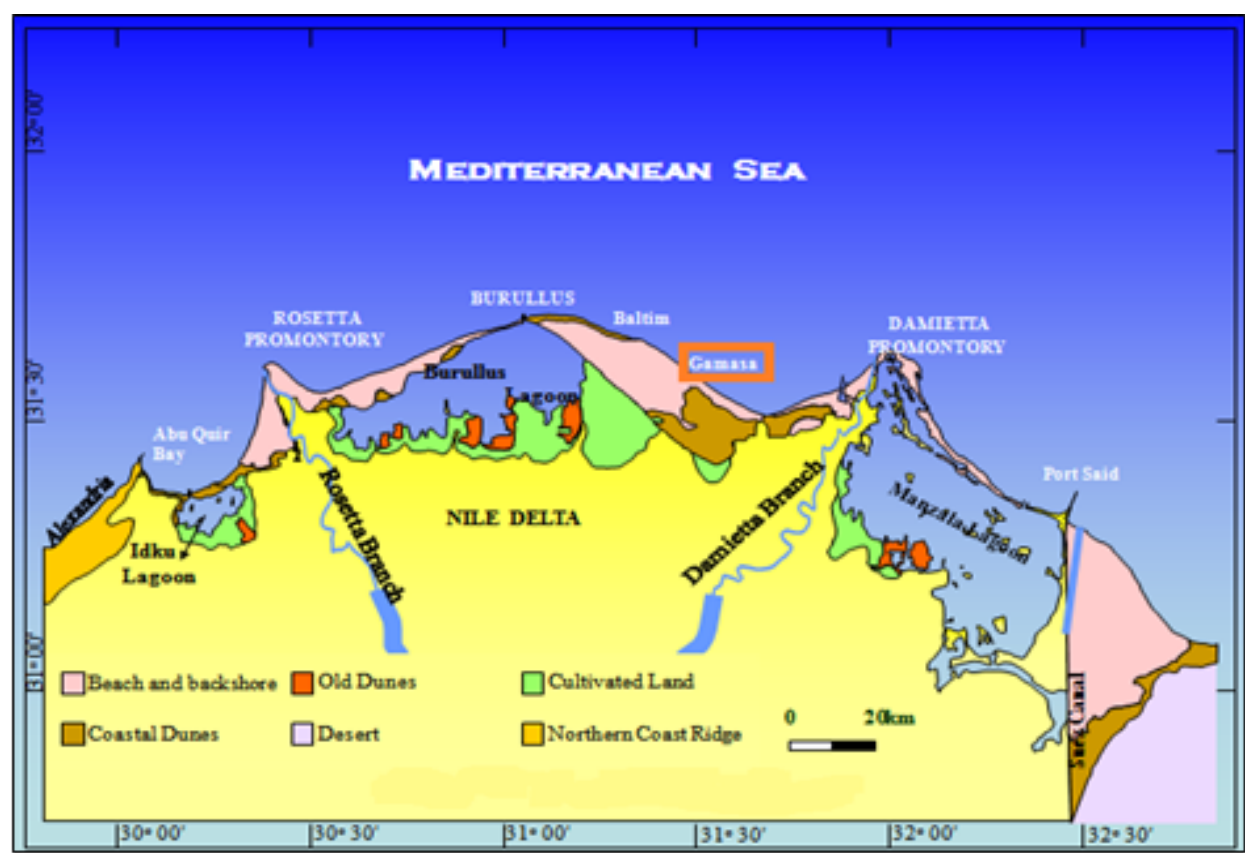

Figure 1: Location of Gamasa Beach along the Nile Delta Coast. 
Citation: El-Sharnouby BA, El-Alfy KS, Rageh OS, El-Sharabasy MM (2015) Coastal Changes along Gamasa Beach, Egypt. J Coast Zone Manag 18: 393. doi: 10.4172/2473-3350.1000393

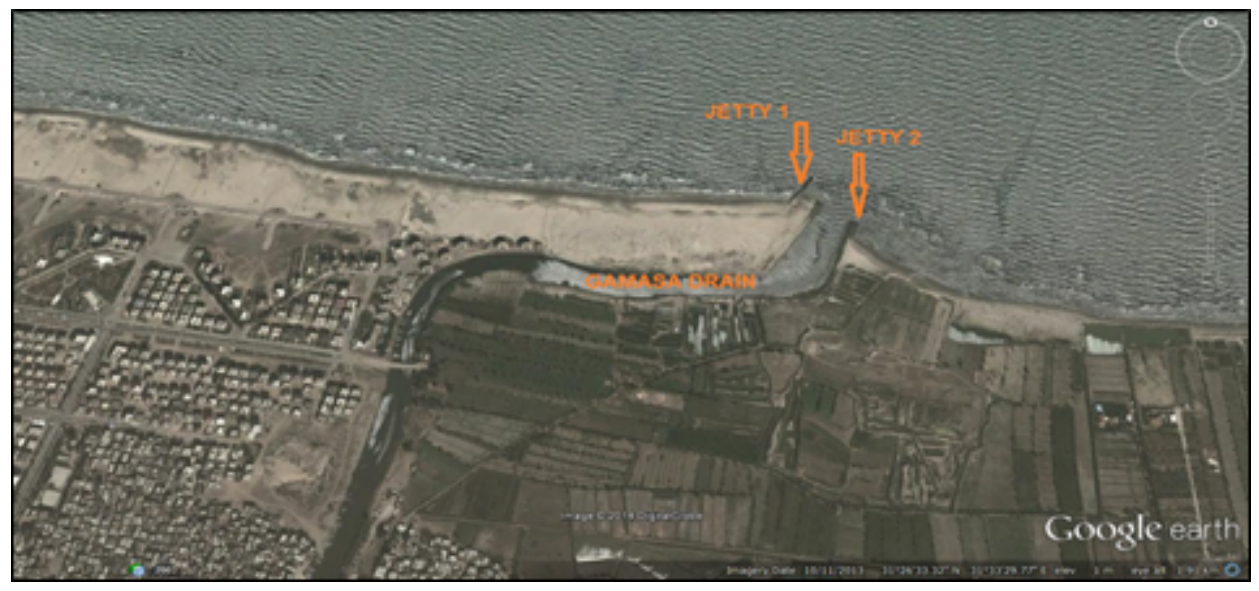

Figure 2: Gamasa drain and two constructed jetties.

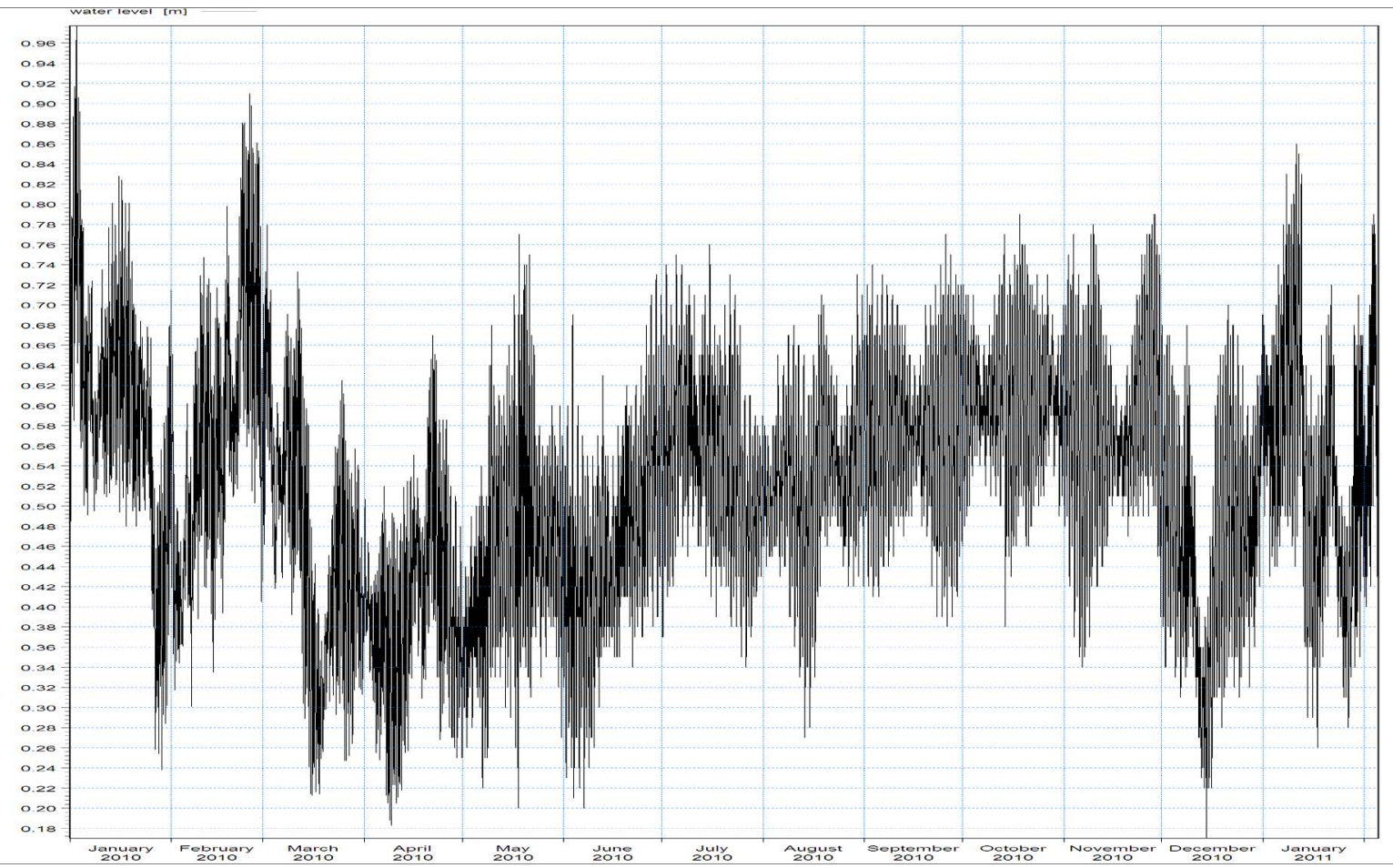

Figure 3: Tide height variation in the study area in the year of 2010

acquisitions to locate the free-surface level. Tides are due to astronomic and meteorological phenomena. In particular, the astronomic tide is due to the gravitational attraction of sun and moon $(30 \%$ and $70 \%$ respectively). It is evaluated by applying the so called harmonic method, that considers the sum of tidal components represented by sinusoidal waves seven components (four semi-diurnal and three diurnal) are enough to have an approximation of one centimeter (NOAA, 1982). Since the selected images were acquired in good weather conditions (calm sea), we neglected the influence of meteorological tide. Tide conditions for our dataset were evaluated using the freeware wxtide32 program (http://www.wxtide32.com/). For the study area, the oscillations of water level (only due to astronomic tide) range between 20 and $70 \mathrm{~cm}$ in a semi-diurnal behavior (oscillation time of about $12 \mathrm{~h}$ and $25 \mathrm{~min}$ ) characterized by two maxima and two minima that are not coincident. The variation of annual average high and low tide height is 0.20 and $0.70 \mathrm{~m}$ (2010) respectively, as shown in Figure 3.

\section{Dataset for Landsat image}

Quantification of the extent of shoreline changes in the Gamasa beach was accomplished using ten landsat images covering a time span 30-year from 1984 to 2014. The details of the satellite imagery, acquisition details and resolutions are given in the Table 1.

\section{Geometric corrections}

The images data were geometrically corrected according to the Universal Transverse Mercator (UTM) map projection system; zone 


\begin{tabular}{|c|c|c|c|c|}
\hline Satellite & Sensor & Scene Path/row & Date & Spatial resolution (meters) \\
\hline Landsat 5 & TM & $176 / 38$ & $7-6-1984$ & $30 m$ \\
\hline Landsat 5 & TM & $177 / 38$ & $31-5-1987$ & $30 m$ \\
\hline Landsat 5 & TM & $177 / 38$ & $15-5-1990$ & $30 m$ \\
\hline Landsat 5 & TM & $177 / 38$ & 9-2-1999 & $30 m$ \\
\hline Landsat 5 & TM & $177 / 38$ & $24-4-2000$ & $30 m$ \\
\hline Landsat 5 & ETM & $177 / 38$ & $22-2-2001$ & $30 m$ \\
\hline Landsat 5 & TM & $176 / 38$ & $17-6-2002$ & $30 m$ \\
\hline Landsat 5 & ETM & $176 / 38$ & $17-4-2003$ & $30 m$ \\
\hline Landsat 7 & ETM & $176 / 38$ & $5-3-2005$ & $30 m$ \\
\hline Landsat 7 & ETM & $176 / 38$ & $17-4-2010$ & $30 m$ \\
\hline Landsat 8 & Oli/TiRs & $177 / 38$ & $25-7-2013$ & $15 \mathrm{~m}$ \\
\hline Landsat 8 & Oli/TiRs & $177 / 38$ & $23-5-2014$ & $15 \mathrm{~m}$ \\
\hline
\end{tabular}

Table 1: Acquired data, sensor type and spatial resolution of Landsat sensors data used in this study.

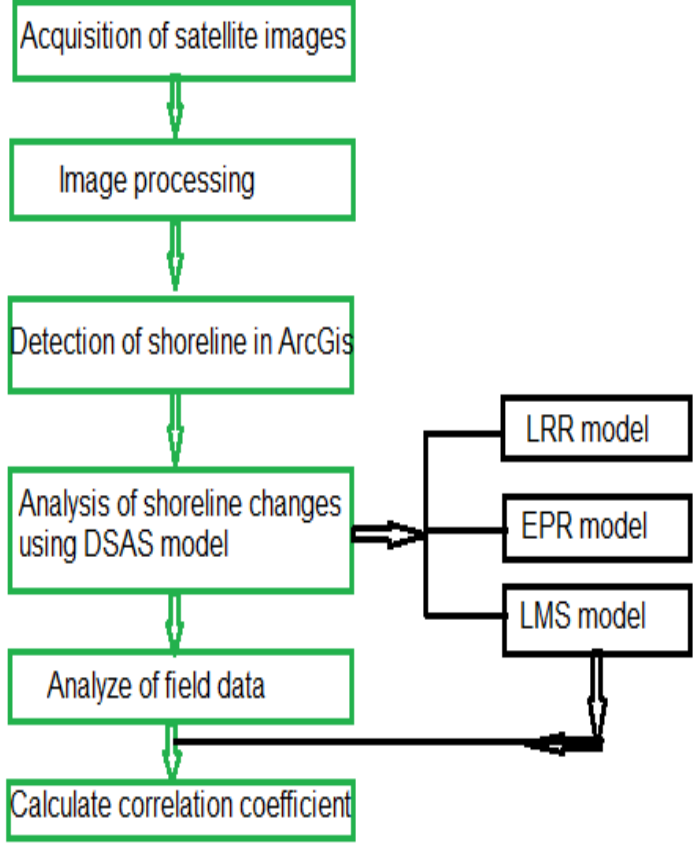

Figure 4: Diagram of the present study workflow.

36 norths, using 37 ground control points (GCPs) that were selected at well-known features using a Geographic Information System (GIS).

\section{Shoreline indictor}

Shoreline Indictor There are many shoreline indicators such as high water line, mean high water line, low water line, and mean tide line. The High Water line (HWL) is the preferred indicator foe shoreline delineation due to easily photo interpretation, field location (Mary and Stephen, 2002). High water line means the line on the land up to which the highest water line reaches during the spring tide. The horizontal location of the mean high water line on a gentle sloping sandy beach, although precisely defined with respect to elevation, highly variables because the beach and foreshore are dynamic. Thus, the use of the high water line is a practical solution to locating the land/sea boundary in a dynamics environment (Pajak and Leatherman, 2002). The position of the high water line is affected by astronomical tides, seasonal beach change, storm events, and wind and tides (Pajak and Leatherman, 2002).

\section{Image processing and shoreline extraction}

Twelve satellite imageries of the years 1984, 1987, 1990, 1999, 2002, 2005, 2010, 2013and 2014 have been taken into consideration in this study. Landsat TM has been resampled to $30 \mathrm{~m}$ to match the spatial resolution of Landsat Oli's images of 2013 and 2014 by using ERDAS Imagine software, 2013 applying layer stack function. Figure 4 illustrates the steps of the developed techniques in this present study. Also, in the present study High Tide Line (HTL) is considered as a shoreline.HTL means the line on the land up to which the highest waterline reaches during the spring tide. Satellite data has been interpreted to demarcate HTL based on various geomorphologic and land use/land cover features like land-ward berm. Arc Map was used to delineated the HTL. The erosion, accretion and stable coast area were found out in overlay techniques in GIS system as shown in Figures 5 and 6.

\section{Rate of shoreline change analysis}

The Digital Shoreline Analysis System (DSAS) was used to determine the rate of change for Gamasa shoreline. All DSAS input data must be managed with in a personal geo database, which includes the baseline and the digitized shorelines for 1984, 1987, 1990, 1999, 2000, 2001, 2002, 2003,2005,2010,2013 and 2014.Baseline was digitized about $300 \mathrm{~m}$, more or less, depending on features and spacing, leeward of the 1984 shoreline. DSAS generated transects perpendicular to the baseline about $50 \mathrm{~m}$ apart, which were manually checked and cleaned up. More than 490 transects were used to calculate the rate of shoreline change along Gamasa beach for about $28-\mathrm{km}$ of shoreline as shown in Figure 7. These rates were calculated using EPR model, LRR model and LMS model in Gis software to identify erosion and accretion areas along Gamasa beach. The End Point Rate (EPR) is calculated by determining the distance between the oldest and most recent shoreline in the data and dividing it by the number of years between them. The LRR is determined by fitting a least-squares regression line to all shoreline points for a particular transects. The regression line is placed so that the sum of the squared residuals (determined by squaring the offset distance of each data point from the regression line and adding the squared residuals together) is minimized. The LMS is determined by an iterative process that calculates all possible values of slope (the rate of change) with in a restricted range of angles. Some of annual rates of shoreline changes determined from analysis of imagery data are presented in Table. Correlation coefficient values of LRR, EPR and LMS are also indicating in Table. Positive and negative values indicate accretion and erosion respectively.

\section{Post-Processed Kinematic (PPK) surveying for Gamasa Beach}

GPS has become a standard surveying technique in most surveying 
Citation: El-Sharnouby BA, El-Alfy KS, Rageh OS, El-Sharabasy MM (2015) Coastal Changes along Gamasa Beach, Egypt. J Coast Zone Manag 18: 393. doi: 10.4172/2473-3350.1000393
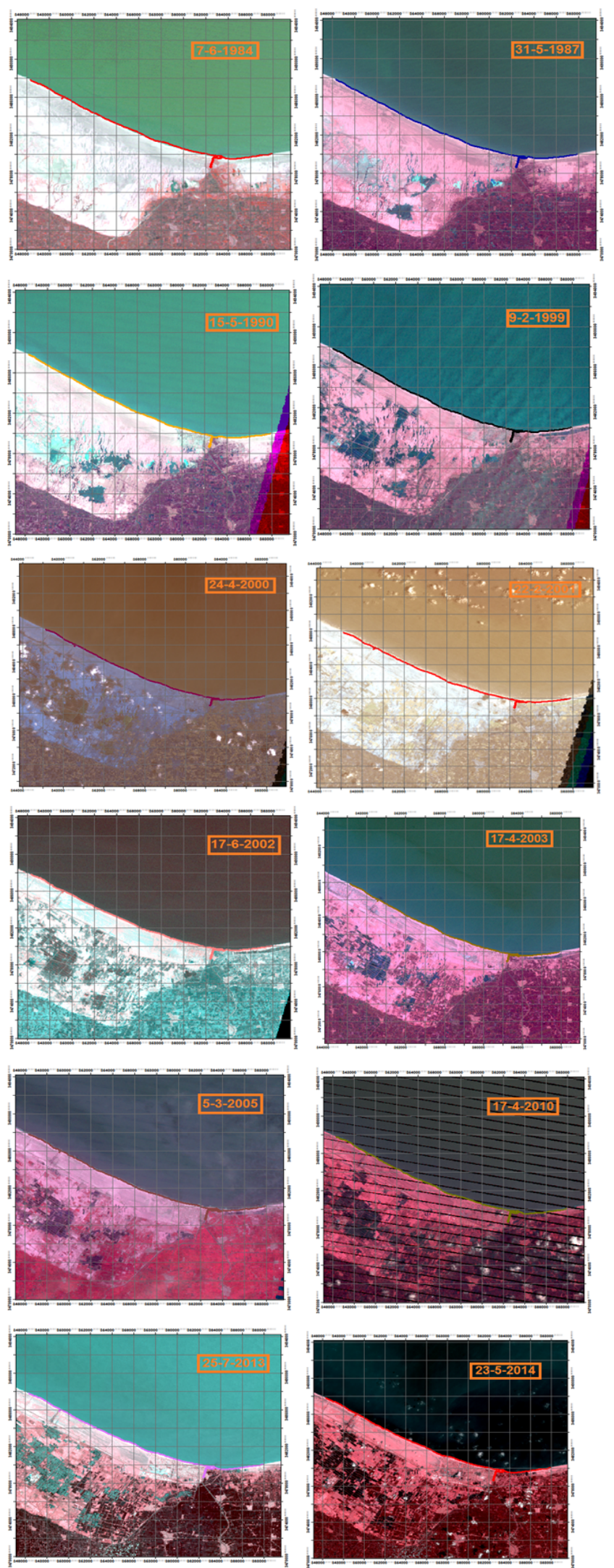

Figure 5: Digitizing of shorelines along Gamasa beach. 
Citation: El-Sharnouby BA, El-Alfy KS, Rageh OS, El-Sharabasy MM (2015) Coastal Changes along Gamasa Beach, Egypt. J Coast Zone Manag 18: 393. doi: 10.4172/2473-3350.1000393

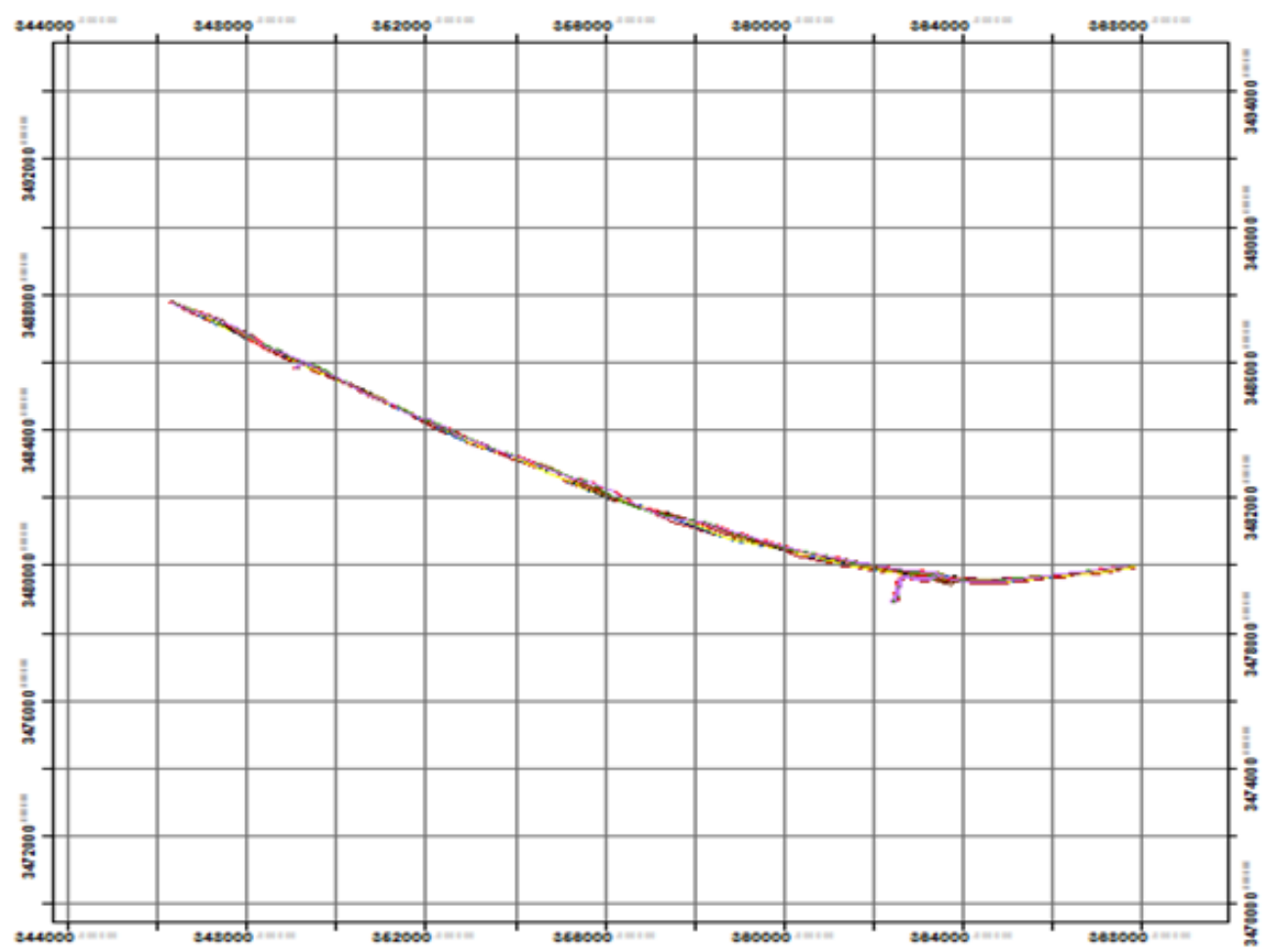

Figure 6: All shorelines for a period between $1984-2014$.

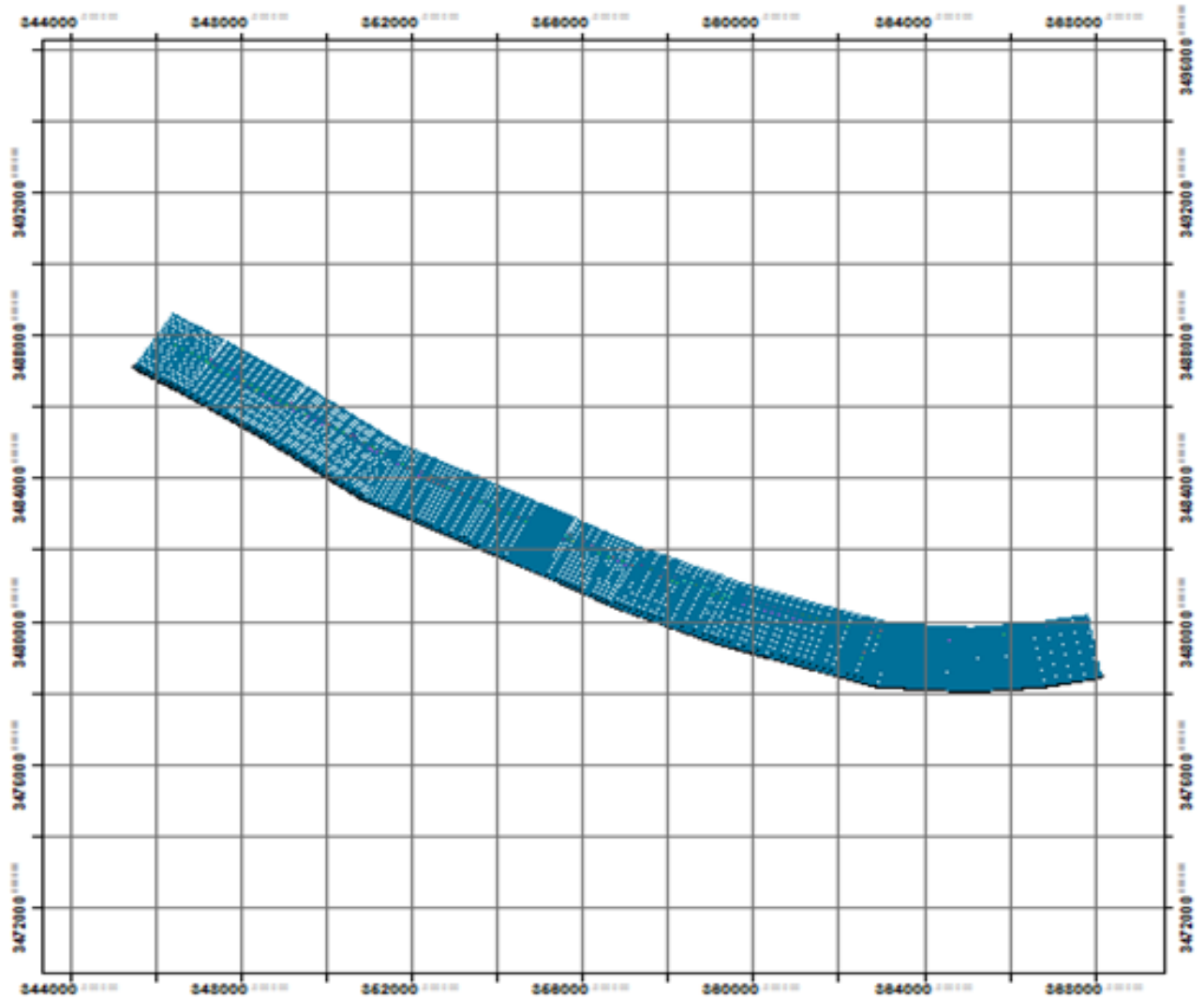

Figure 7: Digitizing shorelines, baseline and transects line. 
Citation: El-Sharnouby BA, El-Alfy KS, Rageh OS, El-Sharabasy MM (2015) Coastal Changes along Gamasa Beach, Egypt. J Coast Zone Manag 18: 393. doi: 10.4172/2473-3350.1000393
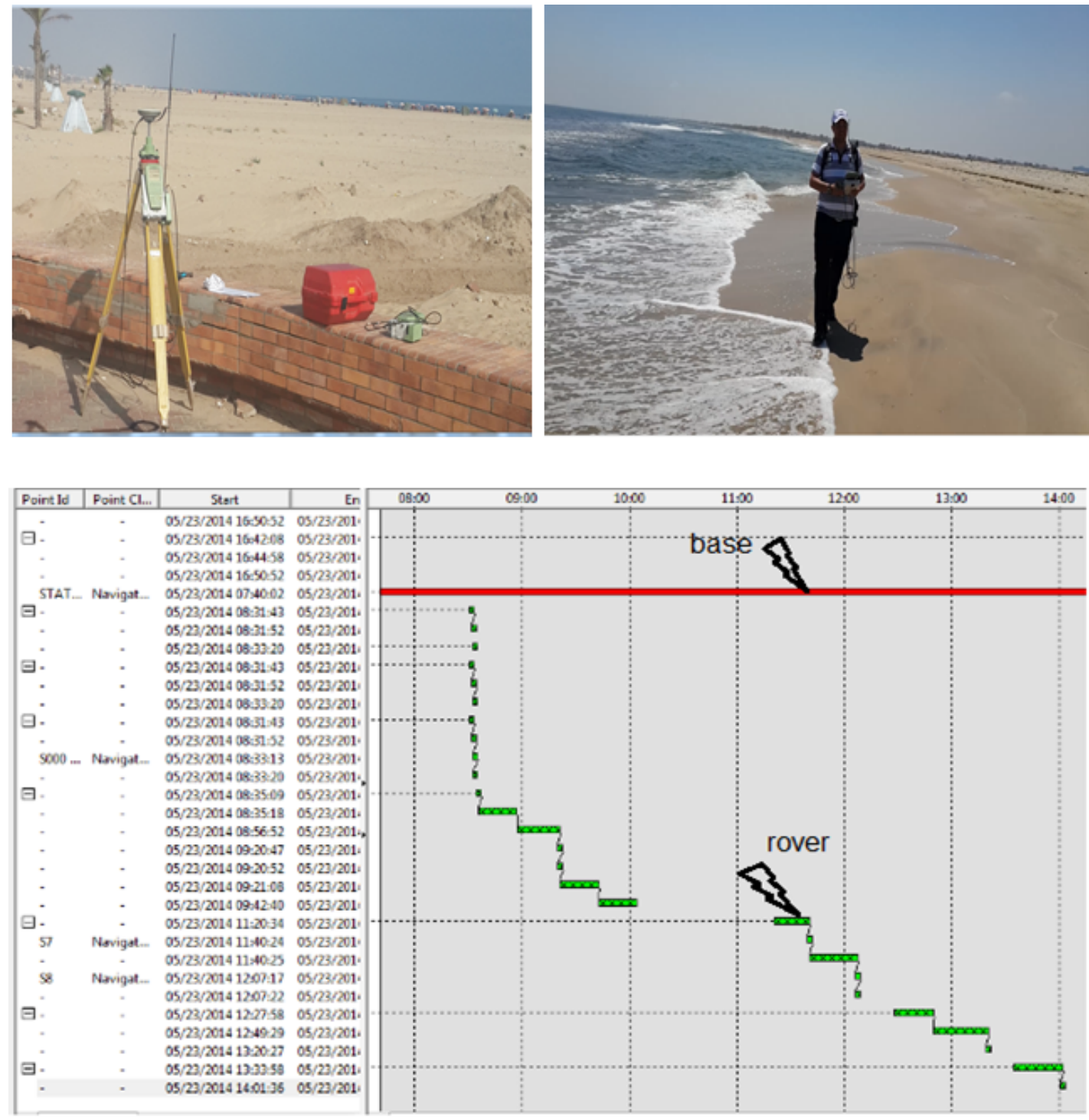

Figure 8: The base GPS antenna and rover station.

practices. This could be attributed to both the ease of use as well as reduction in hardware costs. Post-processed kinematic (PPK) techniques are used for the measurement of details on the shore line 2014 at $28-\mathrm{km}$ for Gamasa beach. PPK surveys require data from at least two receivers: a 'base' (reference) receiver and a 'rover' (moving) receiver. The base GPS antenna can be set up over an existing mark or a newly established mark. The rover can be moved in shoreline which is made for the actual positioning measurements, as shown in Figure 8. All baselines are produced from the GPS unit occupying a reference station to the rover units. Kinematic GPS surveys can be either continuous or "stop and go". Stop and go station observation periods are of short duration, typically under two minutes. The data collected by the rover may be processed and corrected after the measurements have been made, post-processing, to achieve very high precision $(1 \mathrm{~cm} \pm 1 \mathrm{ppm})$. This correction is possible because the base station is located over a stationary point with known coordinates and any deviations from this position can be considered noise and can be removed. The difference in coordinates between the base stations may then be analyzed together with data from the rover to obtain an accurate positioning of the rover relative to the base station; this requires a processing program leica Geo Office 5.0. All manually occupied point is 18 and the quality of points for height and position which reaches about to $0.01 \mathrm{~m}$. Also, the total resulted geographic coordinates after processing for moving points equals 26161.

\section{Results and Discussion}

\section{Shoreline change along Gamasa beach}

Gamasa beach represented $28 \mathrm{~km}$ of the total length of the Nile Delta Coast. Change in shoreline positions were determined by establishing a 490 transects that are oriented perpendiculasr to baseline at $50 \mathrm{~m}$ spacing alongshore by using DSAS software. The annual rates of erosion and accretion calculated from Landsat series using the three different statistical techniques of DSAS (Linear regression rate, End point rate, Least median squares). Figure 9 shows the estimated rates of erosion and accretion along the study alongshore pattern changes 


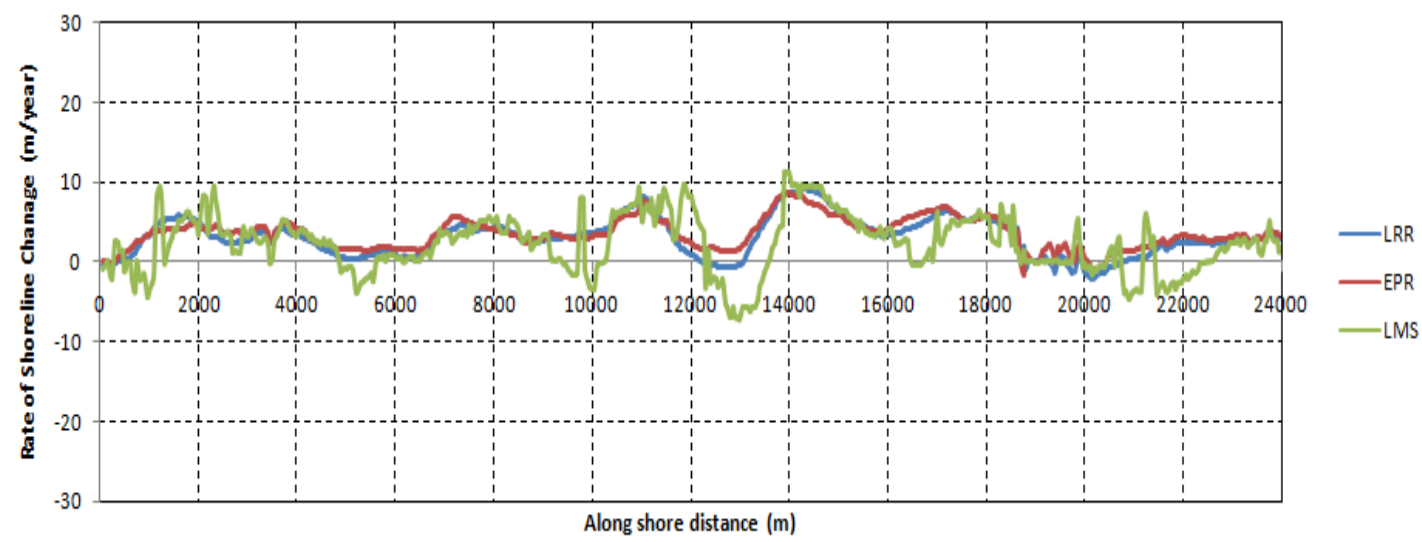

Figure 9: Rate of shoreline change along Gamasa beach from 1984 to 2014

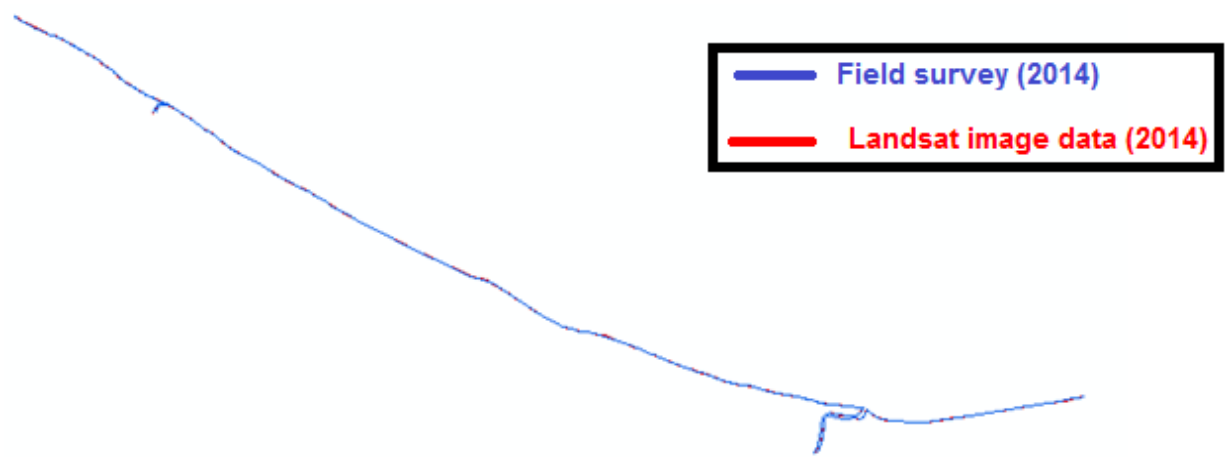

Figure 10: Digitizing shorelines from field data, landsat image and location of profiles for 2014.

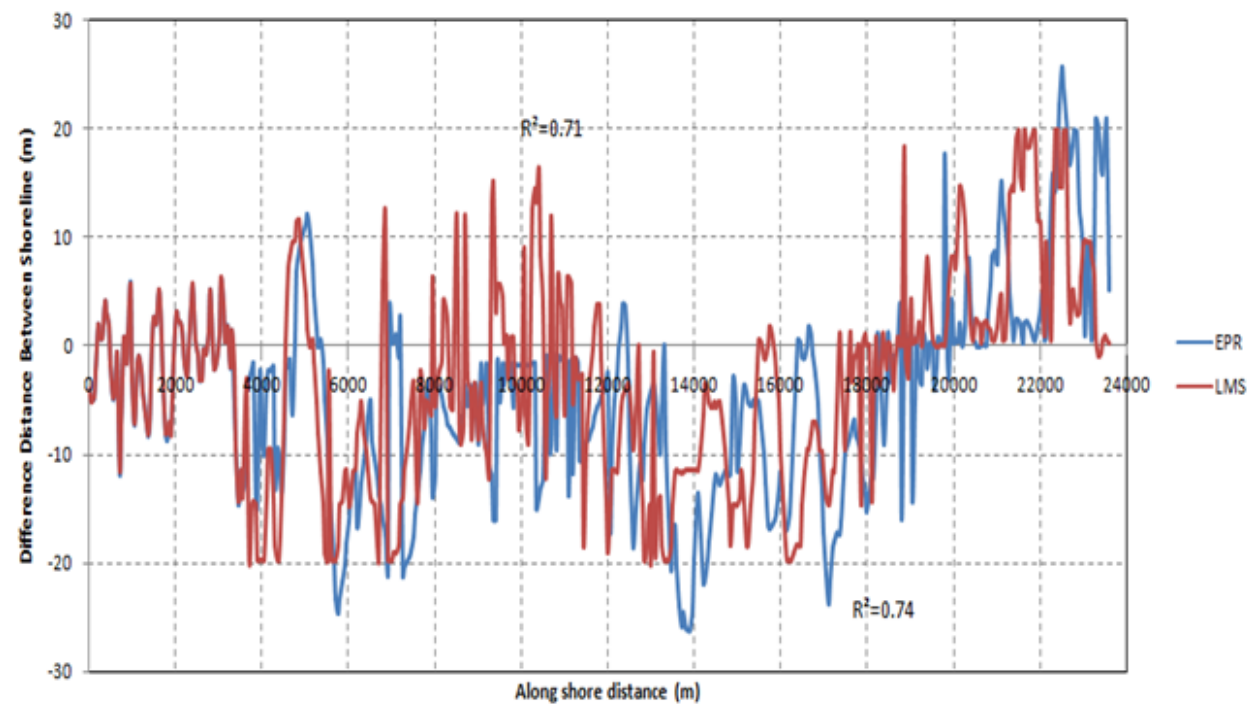

Figure 11: Difference between Landsat data and field data along Gamasa beach for year 2014 by using EPR model and LMS model.

during the examined time intervals (1984-2014). Results showed that the alongshore accretion pattern is apparent phenomena in Gamasa beach with rate of shoreline changes varied between (1.0-9.0) m/year.

On the hand, no significant erosion had appeared in Gamasa beach but the erosion was appeared in a little alongshore with rate of shoreline change varied between (0.30-3.0) $\mathrm{m} /$ year. Such lowest rate of accretion and erosion can be related to the position of Gamasa beach which is located on a very active concave shoreline and protected from wave and current as a result of baltim beach location which is reshaped on a very 
active convex shoreline. Also, this figure identify that the region located in the east of Gamasa beach had lower eroded between 1984-2014 as the construction of two protected jetties at the end of the curved drain.

\section{Model validation}

In Gamasa beach , the results obtained from the analysis of imagery processing were compared by the data calculated from field survey using Post-Processed Kinematic (PPK) Surveying for a year 2014.A total of 493 transects line, that cover the study area have been chosen for validation of beach changes, as shown in Figure 10. The distance between the two shorelines determined from ground survey and those estimated from analysis of imagery data are calculated by using DSAS settings using End point rate model and Least Median Square model. Figure 11 shows the best fit regression line calculated from ground survey measurements and those derived from satellite images (DSAS) by using EPR model and LMS model. It was found that the correlation coefficient for field data and satellite image data is 0.74 using EPR model with difference distance ranged between $(2-20) \mathrm{m}$. Also, the positional shift at each transects line for two shorelines vary between (5-15) $\mathrm{m}$ using LMS model with correlation coefficient is 0.71 .

\section{Prediction model for Gamasa beach}

The prediction accuracy of shoreline position depends on the historical processes (assumed to be captured by Landsat imagery data). In coastline analysis research, extrapolation of a constant rate of change is the most commonly used method to predict the shoreline .Shoreline position change rates are frequently applied to summarize the historical shoreline movements and their future prediction. Several methods have been used for prediction of shoreline position as a function of time, rate of erosion and deposition or sea-level rise such as non-linear mathematical models e.g. higher order polynomial, exponential model, cyclic series models. Among them, the most simple and useful ones are the End Point Rate (EPR) and the Linear Regression Rate (LRR) models. In the present study, the LRR model has been adopted to predict the future shoreline. The model is based on the assumption that the observed periodical rate of change of shoreline position is the best estimate for prediction of the future shoreline. The position of the future shoreline for a given data is estimated using the rate of shoreline movement (slope), time interval between observed and predicted shoreline. In that method the regression equation is used to get a relation between the time and distance from the baseline. The regression equation is given by the formula $(y=m x+b)$ where $(y)$ is the distance from the baseline in meters, $(\mathrm{x})$ is the shoreline date, $(\mathrm{m})$ is the rate of change given from DSAS for each transect, (b) is y-intercept (the value of $\mathrm{y}$ when $\mathrm{x}=0)$ is calculated by the equation [y-intercept $(\mathrm{b})=$ (mean of $\left.y)-(\text { mean of } x)^{*} \mathrm{~m}\right]$. Examples of the estimate of the future scenarios that are obtained using the prediction model for all transects lines with continuous accretion and erosion are shown in Table 2. Also, the estimated position of years 2020, 2030, 2040, 2050 and 2060 shorelines presented in Figure 12. It was observed that during 20142060 the accreation distance along the coastline of Gamasa beach was varied between $(10-200) \mathrm{m}$. Also, the predicted shoreline indicates that the erosion will take place in the western part of Gamasa beach with very small distance varied between $(5-50) \mathrm{m}$.

\section{Summary and Conclusions}

Gamasa beach is one of the most important public beaches along the Nile Delta Coast, Egypt, and represent 28 Kilometers along coastline. Gamasa beach is the less than exposed areas to the processes of erosion and accreation. Gamasa beach remained unprotected until now. Twelve Landsat image (1984, 1987, 1990, 1999, 2000, 2001, 2002, 2003, 2005 , 2010, 2013 and 2014) at unequal intervals along 30 -year period between 1984 and 2014 were processed by the layer stacking function using ERDAS Imagine, 2013 and were digitized using Geographic Information System (GIS) model. Post-Processed Kinematic (PPK) techniques are used for the measurement of details on the shoreline 2014 at $28-\mathrm{km}$ for Gamasa beach. The data collected by the rover and the reference station may be processed using Leica Geo Office 5.0.The number of manually occupied points is 18 and the total moving point by the rover equals 26161. the quality of points for height and position reaches about to $0.01 \mathrm{~m}$.Change in shoreline position were determined by establishing a 490 transects along coastline that are oriented perpendicular to the baseline at $50 \mathrm{~m}$ spacing alongshore by using DSAS model. The rates of erosion and accretion along the study area are calculated from three statistical approaches of DSAS (End point rate, Linear regression rate, Least median of square). To validate results obtained from the analysis of imagery processing, we compared by the data calculated from field survey using Post-Processed Kinematic (PPK) surveying for a year

\begin{tabular}{|c|c|c|c|c|c|c|}
\hline Transects ID & Distance & $\begin{array}{c}\text { Distance from } \\
\text { shoreline } 2014 \text { to2020 }\end{array}$ & $\begin{array}{c}\text { Distance from } \\
\text { shoreline } 2014 \text { to2030 }\end{array}$ & $\begin{array}{c}\text { Distance from } \\
\text { shoreline } 2014 \text { to2040 }\end{array}$ & $\begin{array}{c}\text { Distance from } \\
\text { shoreline } 2014 \text { to2050 }\end{array}$ & $\begin{array}{c}\text { Distance from } \\
\text { shoreline } 2014 \text { to2060 }\end{array}$ \\
\hline 336 & 7900 & 42.63735 & 84.83735 & 127.0374 & 169.2374 & 211.4374 \\
\hline 337 & 7850 & 39.80465 & 82.20465 & 124.6046 & 167.0046 & 209.4046 \\
\hline 338 & 7800 & 36.03154 & 78.43154 & 120.8315 & 163.2315 & 205.6315 \\
\hline 339 & 7750 & 31.02496 & 72.72496 & 114.425 & 156.125 & 197.825 \\
\hline 340 & 7700 & 26.53591 & 67.13591 & 107.7359 & 148.3359 & 188.9359 \\
\hline 341 & 7650 & 21.90217 & 61.30217 & 100.7022 & 140.1022 & 179.5022 \\
\hline 342 & 7600 & 21.25788 & 61.15788 & 101.0579 & 140.9579 & 180.8579 \\
\hline 343 & 7550 & 22.02645 & 63.22645 & 104.4265 & 145.6265 & 186.8265 \\
\hline 344 & 7500 & 22.83674 & 65.33674 & 107.8367 & 150.3367 & 192.8367 \\
\hline 345 & 7450 & 23.37063 & 67.17063 & 110.9706 & 154.7706 & 198.5706 \\
\hline 346 & 7400 & 24.36697 & 69.56697 & 114.767 & 159.967 & 205.167 \\
\hline 347 & 7350 & 24.33984 & 70.13984 & 115.9398 & 161.7398 & 207.5398 \\
\hline 348 & 7300 & 23.40063 & 69.70063 & 116.0006 & 162.3006 & 208.6006 \\
\hline 349 & 7250 & 18.29353 & 63.29353 & 108.2935 & 153.2935 & 198.2935 \\
\hline 350 & 7200 & 12.05171 & 54.55171 & 97.05171 & 139.5517 & 182.0517 \\
\hline 351 & 7150 & 8.584087 & 49.58409 & 90.58409 & 131.5841 & 172.5841 \\
\hline
\end{tabular}

Table 2: Examples on the future estimates for shoreline retreat. 
Citation: El-Sharnouby BA, El-Alfy KS, Rageh OS, El-Sharabasy MM (2015) Coastal Changes along Gamasa Beach, Egypt. J Coast Zone Manag 18: 393. doi: 10.4172/2473-3350.1000393
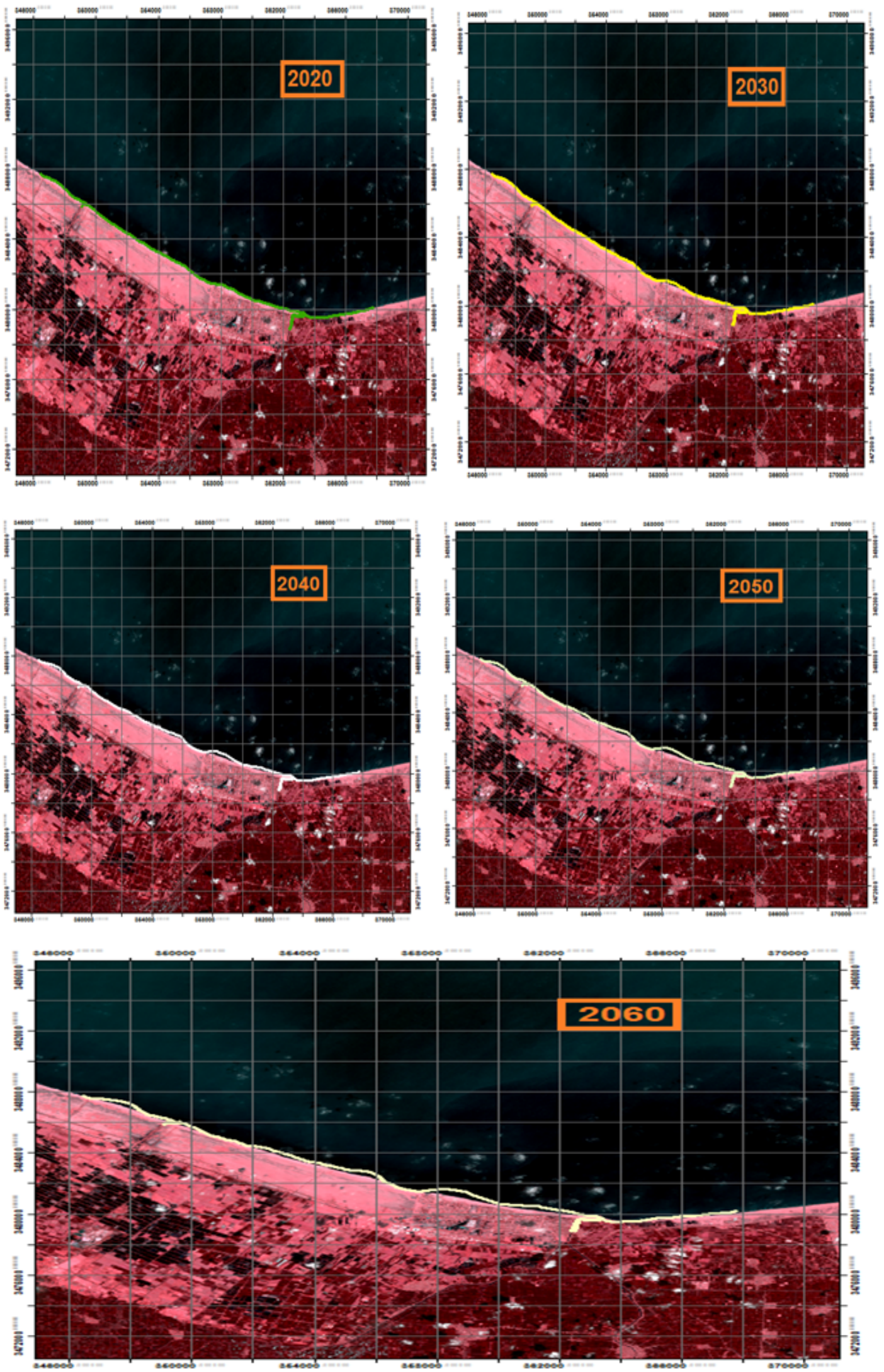

Figure 12: Predicted shorelines 2020, 2030, 2040, 2050 and 2060. 
Citation: El-Sharnouby BA, El-Alfy KS, Rageh OS, El-Sharabasy MM (2015) Coastal Changes along Gamasa Beach, Egypt. J Coast Zone Manag 18: 393. doi: 10.4172/2473-3350.1000393

2014. The correlation coefficient for field data and satellite image data is 0.74 using EPR model and 0.71 using LMS model. Results showed that Gamasa beach had insignificant eroded and lower accretion between 1984 and 2014 with average rates of $5.0 \mathrm{~m} /$ year. The predicted shoreline indicates that during the year of 2014-2060 the accreation distance along the coastline of Gamasa beach was varied between (10-200)m. Also, the erosion will take place in the western part of Gamasa beach with very small distance varied between $(5-50) \mathrm{m}$.

\section{References}

1. Alesheikh AA, Ghorbanali A and Nouri N (2007) "Coastline change detection using remote sensing" Int J. Environ. Sci. Tech 4: 61-66

2. El Banna MM (2009) "Detecting temporal shoreline changes and erosion/ accretion rates, using remote sensing, and their associated sediment characteristics along the coast of North Sinai, Egypt" Journal of Environmental Geology 58: 1419-1427

3. Siripong A (2010) "Detect The Coastline Changes in Thailand by Remote Sensing" International Archives of the Photogrammetry, Remote Sensing and Spatial Information Science 38

4. Dewidar KHM and Frihy OE (2010)"Automated techniques for quantification of beach change rates using Landsat series along the North-eastern Nile Delta, Egypt" Journal of Oceanography and Marina Science, 12: 28-39

5. EL-Asmar HM and Hereher ME (2010) "Change detection of the coastal zone east of the Nile Delta using remote sensing" Journal of Environmental Earth Science, DOI 10.1007/s12665-010-0564-9
6. Kun Yu, Chuanmin Hu, Frank E Muller-Karger, Dianmei Lu (2011) "Shoreline changes in west-central Florida between 1987 and 2008 from Landsat observations" International Journal of Remote Sensing 32: 8299-8313

7. Dewidar KHM (2011) "Changes in the Shoreline Position Caused by Natura Processes for Coastline of Marsa Alam and Hamata, Red Sea, Egypt" International Journal of Geosciences 2: 523-529

8. Prukpitikul S (2012)" Shoreline Change Prediction Model for Coastal Zone Management in Thailand" Journal of Shipping and Ocean Engineering 2: 238243

9. EL-Asmar HM, Hereher ME and EL-Kafrawy SB (2012) "Threats Facing Lagoons along the North Coast of the Nile Delta, Egypt" International Journal of Remote Sensing Applications 2: 24-29

10. Mukhopadhyay A (2012)" Automatic Shoreline Detection and Future Prediction: A case study on Puri Coast, Bay of Bengal, India" Eurpean Journal of Remote Sensing 45: 201-213

11. Mahapatra M (2013)" Shoreline Change Monitoring Along the South Gujarat Coast using Remote Sensing and Gis Techniques" International Journal of Geology, Earth \& Environment Sciences 3: 115-120

12. Niya AK (2013) "Shoreline Change Mapping Using Remote Sensing and Gis" International Journal of Remote Sensing Applications 3

13. Philip (2013) "Medium Resolution Satellite Imagery as a Tool for Monitoring Shoreline Change. Case study of the Eastern coast of Ghana" Journal of Coastal Research 65: 511-520 